\title{
Perancangan Door trim Mobil Sesuai Keinginan Pengguna City Car
}

\author{
Devy Kusumoningtyas Utami ${ }^{* 1)}$, Irwan Iftadi ${ }^{2)}$, dan D. Danardono D.P. ${ }^{3)}$ \\ 1) 2) Program Studi Sarjana Teknik Industri, Fakultas Teknik, Universitas Sebelas Maret \\ Jalan Ir. Sutami 36A, Surakarta 57126, Indonesia \\ 3) Jurusan Teknik Mesin, Fakultas Teknik, Universitas Sebelas Maret \\ Jalan Ir. Sutami 36A, Surakarta 57126, Indonesia
}

\begin{abstract}
Nowadays, product design and development has been driven by market opportunity or known as market pull platform. Aimed to satisfy customer needs, this platform engaged customer at the first stage of the product design and development methods to be represented on the designing stage. The aim of this research is evolve driver door trim design of SmarT EV 2 with customer and ergonomic consideration. The proposed methods, based on combination solution of customers need, has arised four alternative design concepts to be assessed and selected. The choosen design as result is alternative design number four consist of power window and locks feature to enhace safety driving, retractable and electric mirror using knob, side pocket indue cup holder inside, gives dynamical sense by streamline-spherical countour design, and warped arm rest design with its panels layout that used and reached easily.
\end{abstract}

Keywords: door trim design, city car, product design

\section{Pendahuluan}

Daya beli masyarakat Indonesia terhadap kendaraan pribadi khususnya mobil mengalami peningkatan yang cukup pesat. Jenis mobil yang mengalami peningkatan jumlah penjualan diantaranya adalah hatchback / city car. Berdasarkan data Gabungan Industri Kendaraan Bermotor Indonesia (Gaikindo), pada tahun 2012 segmen city car terjual 42.442 unit dan menanjak naik hingga 59.111 unit pada tahun 2013. Pada Januari hingga November 2014 kendaraan tersebut baru terjual 53.353 unit atau setara dengan 4,7 persen dari total pasar otomotif pada periode yang sama sebanyak 1,129 juta unit. Perkembangan jenis mobil city car juga menarik perhatian pemerintah dalam negeri untuk mengembangkan industri otomotif dengan memproduksi kendaraan pribadi yang ramah lingkungan. Galih dan Ngaziz (2012) menyatakan bahwa pada tahun 2012, guna mendukung pengurangan penggunaan BBM, Pemerintah Republik Indonesia menggalakkan lahirnya Mobil Listrik Nasional atau disebut juga sebagai Molina (Febza, 2014). Salah satu universitas yang mengembangkan Molina adalah UNS dengan mengadopsi eksterior Toyota Yaris sebagai jenis mobil hatchback. Ditinjau dari jenis mobil yang ada, hatchback termasuk dalam jenis mobil unik dengan fitur khusus lift gate/hatch atau pintu bagasi belakang yang menjadi satu dengan bagian kursi penumpang belakang (Macey and Wardle, 2008).

Pada umumnnya, tujuan pengembangan produk adalah melakukan perbaikan dan memodifikasi tampilan serta fungsi produk untuk meningkatkan kepuasan konsumen (Ishioka and Yasuda, 2009). Hal ini sesuai dengan pernyataan Johnson (2007) bahwa strategi pengembangan produk terbaik yakni "semakin dekat dengan konsumen". Dijelaskan pula oleh Karkainen dkk. (2001) dan Bergquist dkk. (1996) bahwa, untuk mencapai kesuksesan pengembangan produk diperlukan pemahaman yang mendalam pada konsumen meliputi

*Correspondance : devykusumo@student.uns.ac.id 
kondisi, kebutuhan dan keinginan pengguna pada produk tersebut. Pengguna sebagai end user dapat dilibatkan secara aktif dalam metode pengoptimalan produk (Lagrosen, 2005).

Bersamaan dengan proses pengembangan produk yang berada pada kondisi market pull, yakni kondisi dimana perusahaan memulai pengembangan produk dengan adanya peluang pasar dan kemudian menggunakan teknologi apa saja yang yang tersedia untuk memenuhi kebutuhan pelanggan. Proses perencanaan ini diharapkan mampu memenuhi kebutuhan pelanggan dimana posisinya sama pentingnya dengan produk yang mengalami perubahan secara revolusioner maupun produk yang berkembang secara bertahap (Ulrich dan Eppringer, 2001). Sedangkan karakter produk yang dibutuhkan untuk mencapai kesuksesan yaitu kemampuan produk untuk menawarkan manfaat yang diinginkan pelanggan. Hal ini berlaku untuk produk variasi atau perbaikan kecil dari produk yang sudah ada maupun produk baru yang revolusioner.

Salah satu bagian interior yang bekerja secara aktif yakni instrumen panel pada door trim yang berkaitan dengan keamanan dan keselamatan penumpang menjadi objek penelitian ini. Dengan tujuan untuk mengembangan rancangan door trim Mobil Listrik Nasional UNS Generasi ke-2 dan melakukan perancangan interior sesuai prinsip untuk meminimalisir resiko kecelakaan, baik dalam pengoperasian maupun kefatalan sesuai dengan istilah "the interior must be safe" (Macey and Wardley, 2008), maka pada tahap perancangan komponen produk otomotif seperti mobil dilakukan perancangan yang melibatkan pengguna (human factor). Penentuan ukuran/dimensi dalam perancangan interior juga mempengaruhi keergonomisan produk terkait (Mohamed and Yusuff, 2007). Oleh karena itu, untuk mendapatkan produk otomotif yang memberikan kenyamanan bagi pengguna, dalam penelitian ini dibahas tentang perancangan door trim sesuai keinginan pengguna yang memperhatikan aspek ergonomis.

\section{Metode Penelitian}

Metode penelitian menjelaskan tentang tahapan penelitian yang terdiri dari enam tahap yakni perencanaan, identifikasi kebutuhan pelanggan, penetapan spesifikasi target, penyusunan konsep desain, pemilihan konsep dan analisis hasil yang diakhiri dengan kesimpulan. Selain itu, dalam penelitian terdapat beberapa batasan permasalahan yaitu spesifikasi perancangan door trim yang dibuat berdasarkan identifikasi kebutuhan pelanggan, dimensi perancangan disesuaikan yang dengan dimensi door trim Mobil Listrik Nasional UNS Smart EV.2 dan responden penelitian yang merupakan pengemudi city car.

Tahap perencanaan sebagai tahap awal penelitian terdiri dari 2 aktivitas yaitu observasi dan wawancara. Aktivitas observasi dilakukan pada awal penelitian dengan pengamatan secara langsung mengenai komponen door trim yang sudah di pasaran dan pada salah satu city car yang dikembangkan oleh tim Mobil Listrik Nasional UNS. Pada tahap ini, ditentukan jumlah responden sebanyak 15 orang. Jumlah responden dipilih berdasarkan matriks pemilihan pelanggan dan dapat dihentikan apabila tidak ada kebutuhan baru dari tambahan wawancara yang dilakukan (Ulrich dan Eppringer, 2001).

Tahap kedua yakni identifikasi kebutuhan pelanggan yang dilakukan dengan wawancara langsung kepada pengguna city car. Tujuan dari wawancara adalah mengetahui pendapat pengguna mengenai fitur yang terdapat pada door trim dan mengumpulkan informasi tentang kebutuhan pelanggan terhadap komponen door trim yang akan menjadi dasar perancangan door trim. Pertanyaan disusun berdasarkan kebutuhan perancangan mengenai estetika dan fungsional produk yang terbagi menjadi beberapa subjek. Hasil wawancara merupakan data mentah yang kemudian disusun menjadi daftar kebutuhan pelanggan sesuai tahapan identifikasi kebutuhan pelanggan.

Tahap ketiga yakni penetapan spesifikasi target yang dilakukan untuk mengungkapkan detail-detail yang tepat dan terukur mengenai apa yang harus dilakukan produk. Hasil dari tahap 
ini ditampilkan dalam daftar metrik yang berisi kebutuhan pelanggan dan daftar pernyataan tentang bagaimana produk mampu memenuhi kebutuhan tersebut.

Tahap penyusunan konsep door trim menggambarkan secara singkat mengenai cara produk memuaskan kebutuhan pelanggan. Proses penyusunan konsep terdiri dari beberapa tahapan yakni memperjelas masalah, pencarian eksternal, pencarian internal dan menyusun konsep menggunakan tabel kombinasi konsep. Pemilihan konsep desain produk dilakukan sesuai dengan alternatif konsep yang didapatkan dari tahap sebelumnya. Proses pemilihan konsep desain terdiri dari 5 tahapan antara lain mempersiapkan matriks seleksi, menilai konsep, meranking konsep, mengkombinasikan dan memperbaiki konsep serta menampilkan hasilnya. Masing-masing alternatif rancangan dipilih oleh tim, yakni orang-orang yang berasal dari kelompok fungsional yang berbeda dalam organisasi. Sehingga kemudian, didapatkan alternatif rancangan terbaik berdasarkan keputusan tim.

Tahapan selanjutnya yaitu analisis hasil dan kesimpulan, dimana analisis dilakukan terhadap hasil pengolahan data yakni beberapa alternatif rancangan door trim mobil sehingga didapatkan desain door trim mobil terbaik. Setiap alternatif rancangan yang sebelumnya dinilai/diranking, kemudian dapat diidentifikasi kelebihan dan kelemahannya untuk memberikan alternatif rancangan yang terbaik.

\section{Hasil dan Pembahasan}

\subsection{Perencanaan}

Observasi dilakukan dengan mengamati secara langsung desain door trim pintu pengemudi pada mobil city car yang dipasarkan oleh produsen otomotif di Indonesia. Observasi dilakukan pada 10 jenis city car dan Mobil Listrik UNS Generasi ke-2. Pada setiap city car diamati komponen yang terdapat pada door trim, apabila terdapat komponen baru yang tidak ada pada jenis mobil sebelumnya maka ditambahkan. Sehingga akan ditemukan adanya perbedaan komponen pada masing-masing jenis mobil. Teknik yang digunakan untuk menampilkan hasil observasi pada setiap city car adalah check list yang menjelaskan keberadaan komponen pada door trim mobil terkait. Hasil observasi dijelaskan pada tabel 1 dan keberadaan komponen door trim pada keseluruhan interior mobil dijelaskan pada tabel 2.

Tabel 1. Hasil Observasi

\begin{tabular}{|c|c|c|c|c|c|c|c|c|c|c|c|}
\hline Komponen & $\begin{array}{l}\text { Honda } \\
- \\
\text { Jazz }\end{array}$ & $\begin{array}{l}\text { Honda } \\
- \\
\text { Brio }\end{array}$ & $\begin{array}{l}\text { Toyota } \\
- \\
\text { Yaris }\end{array}$ & $\begin{array}{l}\text { Toyota } \\
- \\
\text { Etios } \\
\text { Valco }\end{array}$ & $\begin{array}{l}\text { Mitsubitshi } \\
- \\
\text { Mirage } \\
\text { GLS }\end{array}$ & $\begin{array}{l}\text { Kia } \\
- \\
\text { All } \\
\text { New } \\
\text { Picanto }\end{array}$ & $\begin{array}{l}\text { Suzuki } \\
- \\
\text { Splash }\end{array}$ & $\begin{array}{l}\text { Nissan } \\
- \\
\text { March }\end{array}$ & $\begin{array}{l}\text { Ford } \\
- \\
\text { Fiesta }\end{array}$ & $\begin{array}{l}\text { Hyu } \\
\text { ndai } \\
- \\
\text { I10 }\end{array}$ & $\begin{array}{l}\text { Molina } \\
\text { UNS - } \\
\text { SmarT } \\
\text { EV } 2\end{array}$ \\
\hline Arm rest & $\mathrm{V}$ & $\mathrm{V}$ & $\mathrm{V}$ & $\mathrm{V}$ & $\mathrm{V}$ & $\mathrm{V}$ & $\mathrm{V}$ & $\mathrm{V}$ & $\mathrm{V}$ & $\mathrm{V}$ & $\mathrm{V}$ \\
\hline $\begin{array}{l}\text { Power } \\
\text { window }\end{array}$ & $\mathrm{v}$ & $\mathrm{V}$ & $\mathrm{v}$ & $\mathrm{v}$ & $\mathrm{v}$ & $\mathrm{v}$ & V & $\mathrm{v}$ & $\mathrm{v}$ & $\mathrm{v}$ & V \\
\hline $\begin{array}{l}\text { Auto } \\
\text { Power } \\
\text { window }\end{array}$ & $\mathrm{v}$ & $\mathrm{V}$ & $\mathrm{v}$ & $\mathrm{v}$ & - & $\mathrm{v}$ & $\mathrm{v}$ & $\mathrm{v}$ & $\mathrm{v}$ & $\mathrm{v}$ & $\mathrm{v}$ \\
\hline Door lock & $\mathrm{v}$ & $\mathrm{v}$ & $\mathrm{V}$ & $\mathrm{v}$ & $\mathrm{v}$ & $\mathrm{v}$ & $\mathrm{v}$ & $\mathrm{v}$ & $\mathrm{V}$ & $\mathrm{v}$ & $\mathrm{V}$ \\
\hline Handle & $\mathrm{v}$ & $\mathrm{V}$ & $\mathrm{v}$ & $\mathrm{v}$ & $\mathrm{v}$ & $\mathrm{v}$ & $\mathrm{v}$ & $\mathrm{v}$ & $\mathrm{v}$ & $\mathrm{v}$ & - \\
\hline Speaker & $\mathrm{v}$ & $\mathrm{V}$ & $\mathrm{v}$ & $\mathrm{v}$ & $\mathrm{v}$ & - & $\mathrm{v}$ & $\mathrm{v}$ & $\mathrm{v}$ & $\mathrm{v}$ & $\mathrm{v}$ \\
\hline $\begin{array}{l}\text { Door } \\
\text { Pocket/Cup } \\
\text { holder }\end{array}$ & $\mathrm{V}$ & $\mathrm{V}$ & $\mathrm{v}$ & $\mathrm{v}$ & $\mathrm{v}$ & $\mathrm{v}$ & $\mathrm{v}$ & $\mathrm{v}$ & $\mathrm{v}$ & $\mathrm{V}$ & - \\
\hline $\begin{array}{l}\text { Tombol } \\
\text { Central } \\
\text { Lock }\end{array}$ & $\mathrm{v}$ & - & $\mathrm{v}$ & $\mathrm{v}$ & - & $\mathrm{v}$ & $\mathrm{v}$ & $\mathrm{v}$ & $\mathrm{v}$ & $\mathrm{v}$ & $\mathrm{v}$ \\
\hline
\end{tabular}


Keterangan simbol :

$\mathrm{v}$ : terdapat komponen terkait pada door trim mobil.

- : tidak terdapat komponen terkait pada door trim mobil.

Tabel 2. Keterangan Komponen pada Interior Mobil

\begin{tabular}{ll}
\hline \multicolumn{1}{c}{ Komponen } & \multicolumn{1}{c}{ Keterangan } \\
\hline Arm rest & Semua jenis city car dilengkapi arm rest untuk peletakan instrumen panel. \\
Power window & Fitur ini sudah ada pada semua jenis city car. \\
Auto Power window & Fitur ini belum terdapat pada interior mobil Mirage tipe GLS. \\
Door lock & Fitur ini sudah ada pada semua jenis city car. \\
Handle & Fitur ini tidak ditemukan dalam door trim Molina UNS Generasi ke-2. \\
Speaker & Pada door trim mobil All New Picanto tidak terdapat spekar, tetapi speaker terdapat \\
poor Pocket/Cup & Fitur ini belum ada pada bagian interior Molina UNS Generasi ke-2. \\
holder & \\
Tombol Central Lock & Penguncian terpusat/central lock belum ada pada Honda Brio dan Mirage tipe GLS \\
& yang digunakan dalam penelitian ini. \\
\hline
\end{tabular}

\subsection{Identifikasi Kebutuhan Pelanggan}

Wawancara dilakukan terhadap 13 orang responden yakni pengguna city car mengenai door trim mobil yang digunakan. Jumlah ini adalah cukup untuk merepresentasikan kebutuhan pengguna, sehingga tidak dilakukan wawancara lagi karena tidak didapatkan tambahan informasi yang signifikan. Hasil yang didapatkan dari wawancara merupakan data mentah yang diterjemahkan menjadi daftar kebutuhan pelanggan dan disusun dalam hierarki kebutuhan sesuai tabel 3 berikut.

Tabel 3. Hierarki Kebutuhan Perancangan Door trim

\begin{tabular}{|c|c|c|}
\hline No. & Kebutuhan Primer & Kebutuhan Sekunder \\
\hline 1. & $\begin{array}{l}\text { Door trim dilengkapi dengan komponen } \\
\text { yang menunjang keamanan pengguna. }\end{array}$ & $\begin{array}{l}\text { Terdapat fitur automatic power window. } \\
\text { Terdapat fitur central door lock. } \\
\text { Terdapat fitur door lock. } \\
\text { Terdapat fitur power wsindow untuk semua pintu. }\end{array}$ \\
\hline 2. & Door trim memberikan kesan dinamis. & $\begin{array}{l}\text { Desain door trim dinamis. } \\
\text { Terdapat kombinasi warna. } \\
\text { Terdapat kombinasi warna untuk menghilangkan kesan } \\
\text { polos. }\end{array}$ \\
\hline 3. & Terdapat pengaturan spion pada door trim & $\begin{array}{l}\text { Terdapat fitur pengaturan spion termasuk mengatur arah } \\
\text { cermin. } \\
\text { Terdapat fitur retractable mirror dan electric mirror. } \\
\text { Tombol pengaturan spion diletakkan berdekatan dengan } \\
\text { roda kemudi. } \\
\text { Fitur pengaturan spion diletakkan sesuai tombol lainnya. }\end{array}$ \\
\hline 4. & $\begin{array}{l}\text { Door trim dilengkapi dengan wadah serba } \\
\text { guna }\end{array}$ & $\begin{array}{l}\text { Terdapat wadah untuk koin receh. } \\
\text { Ukuran kotak receh muat untuk beberapa receh. }\end{array}$ \\
\hline 5. & $\begin{array}{l}\text { Door trim dilengkapi dengan handle pintu } \\
\text { yang mudah digenggam. }\end{array}$ & $\begin{array}{l}\text { Handle pintu sesuai dengan genggaman tangan. } \\
\text { Handle pintu tidak berlubang. } \\
\text { Handle lock mobil mudah digunakan. }\end{array}$ \\
\hline 6. & $\begin{array}{l}\text { Door trim dilengkapi dengan wadah untuk } \\
\text { menyimpan botol minum }\end{array}$ & $\begin{array}{l}\text { Ukuran cup holder disesuaikan dengan kebutuhan } \\
\text { konsumen. } \\
\text { Terdapat cup holder/wadah air minum. } \\
\text { Ukuran cup holder sesuai dengan botol air mineral } 600 \mathrm{ml} \text {. } \\
\text { Ukuran cup holder disesuaikan dengan kebutuhan pengguna } \\
\text { Bentuk cup holder mengikuti kontur botol minum. }\end{array}$ \\
\hline 7. & $\begin{array}{l}\text { Komponen pada door trim mudah } \\
\text { dioperasikan pengguna. }\end{array}$ & $\begin{array}{l}\text { Letak dan desain tombol power window memudahkan } \\
\text { pengguna dalam mengoperasikan. } \\
\text { Tombol pengaturan jendela diletakkan dalam proporsi yang } \\
\text { tepat. } \\
\text { Lebar arm rest disesuaikan dengan kebutuhan pengguna. } \\
\text { Desain handle lock mudah digunakan pengguna. } \\
\text { Letak power window memudahkan pengguna ketika }\end{array}$ \\
\hline
\end{tabular}




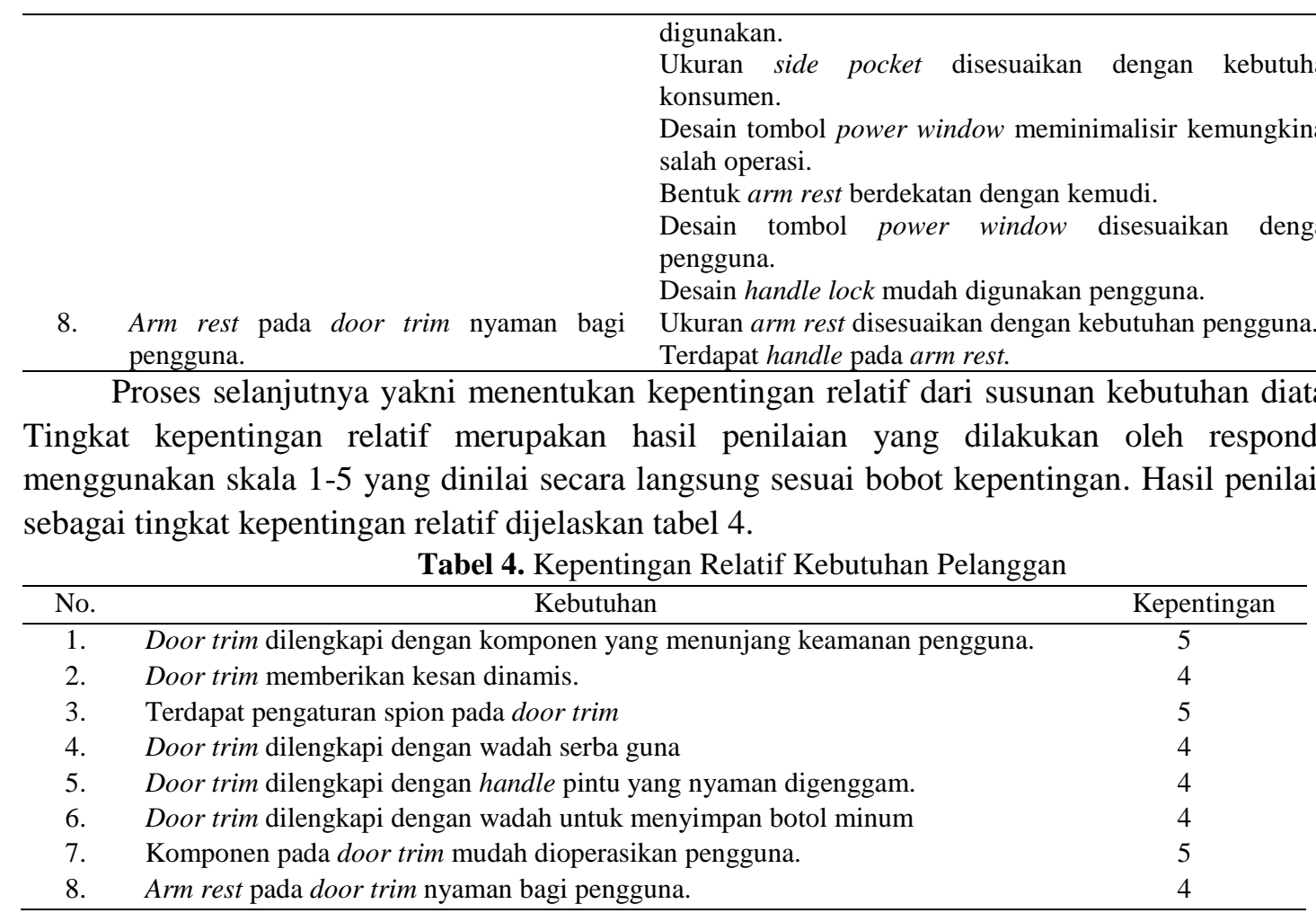

Keterangan :

Bobot kepentingan yang dinyatakan dalam angka dijelaskan sebagai berikut :

\begin{tabular}{cl}
\hline Bobot kepentingan & \multicolumn{1}{c}{ Kriteria } \\
\hline 1 & Kriteria ini tidak diinginkan dan tidak akan saya pertimbangkan dalam memilih mobil. \\
2 & Kriteria ini tidak penting dan saya tidak berfikir untuk memikirkannya. \\
4 & Kriteria ini bagus untuk dimiliki, namun tidak terlalu diperlukan. \\
5 & Kriteria ini penting, tetapi bukan menjadi pertimbangan saya dalam memilih produk. \\
\hline
\end{tabular}

\subsection{Penentuan Spesifikasi Target}

Spesifikasi produk yang dilakukan pada tahap ini merupakan spesifikasi target sebelum produk didesain/dirancang. Spesifikasi target ini berisi pernyataan yang tidak mendua mengenai apa yang harus diusahakan oleh tim dalam upaya memuaskan kebutuhan pelanggan. Spesifikasi target untuk perancangan door trim dijelaskan dalam tabel 5 berupa daftar metrik yang terdiri dari lima kolom yaitu nomor metrik, kebutuhan, metrik, kepentingan dan satuan yang menjelaskan nilai metrik. Nilai Subj. berarti subyektifitas yang menjelaskan metrik kebutuhan pelanggan yang tidak diterjemahkan.

Tabel 5. Daftar Metrik untuk Door trim

\begin{tabular}{cclcc}
\hline $\begin{array}{c}\text { No. } \\
\text { Metrik }\end{array}$ & Kebutuhan & \multicolumn{1}{c}{ Metrik } & $\begin{array}{c}\text { Kepen- } \\
\text { tingan }\end{array}$ & $\begin{array}{c}\text { Satuan } \\
\text { 1 }\end{array}$ \\
\hline 1 & 1 & Komponen pengunci mobil dan kaca jendela & 5 & volume \\
2 & 2 & Memberikan kesan dinamis & 4 & Subj. \\
3 & 3 & Alat untuk konfigurasi spion & 5 & volume \\
4 & 4 & Wadah serbaguna & 4 & volume \\
5 & 5 & Desain komponen & 4 & mm \\
6 & 5 & Tata letak komponen/panel & 4 & mm \\
7 & $5,6,8$ & Dimensi alat & 4 & mm \\
8 & 6 & Antropometri genggaman tangan & 4 & mm \\
9 & 7 & Wadah untuk botol minum & 4 & volume \\
10 & 2,8 & Desain ruang kemudi & 4 & Subj. \\
11 & 8 & Dimensianthropometri tangan & 4 & mm \\
\hline
\end{tabular}




\subsection{Penyusunan Konsep Desain Door trim}

Berdasarkan hasil penilaian pada tabel 4 diketahui bahwa semua kriteria yang disusun merupakan kriteria yang dianggap penting dalam produk door trim yang dikembangkan. Sehingga pada tahap ini, kebutuhan tersebut diuraikan menjadi sub masalah menggunakan teknik dekomposisi masalah untuk memperjelas permasalahan dan melakukan pencarian solusi secara internal dan eksternal. Setiap solusi pada permasalahan tersebut kemudian dituliskan dalam tabel kombinasi konsep yang dijelaskan dalam tabel 6 dan dilakukan kombinasi pada setiap kolom solusi hingga didapatkan empat alternatif desain pada gambar 2 berikut.

Alternatif rancangan yang muncul pada penelitian ini berjumlah empat buah sebagai hasil kombinasi dari solusi pada setiap sub masalah. Pada mulanya, kombinasi konsep dilakukan untuk setiap sub masalah yang terdiri dari 6 kriteria. Namun beberapa kriteria memiliki solusi yang tidak terkait secara langsung dengan rancangan door trim, akan tetapi lebih berkaitan dengan sistem elektronik dalam rangkaian instrumen panel atau disebutkan lebih independen terkait sistem kendalinya. Selain itu, dengan kombinasi 6 kriteria sub masalah dan solusi yang disebutkan, maka akan muncul 48 alternatif pada rancangan door trim ini. Oleh karena itu, dengan pertimbangan tersebut, kemudian disusun kombinasi konsep baru yang terdiri dari tiga kriteria sub masalah. Tiga kriteria sub masalah yang dipilih antara lain komponen lain yang menunjang keamanan pengguna, bentuk wadah serbaguna dan kenyamanan arm rest yang kemudian di kombinasikan berdasarkan solusi yang muncul dari pencarian internal dan eksternal. Kombinasi dilakukan pada setiap solusi dengan menghubungkan setiap solusi pada satu kriteria dengan solusi dari kriteria yang lain. Dari tiga kriteria sub masalah tersebut, kemudian muncul empat kombinasi hubungan yang menjadi dasar perancangan dalam alternatif rancangan door trim.

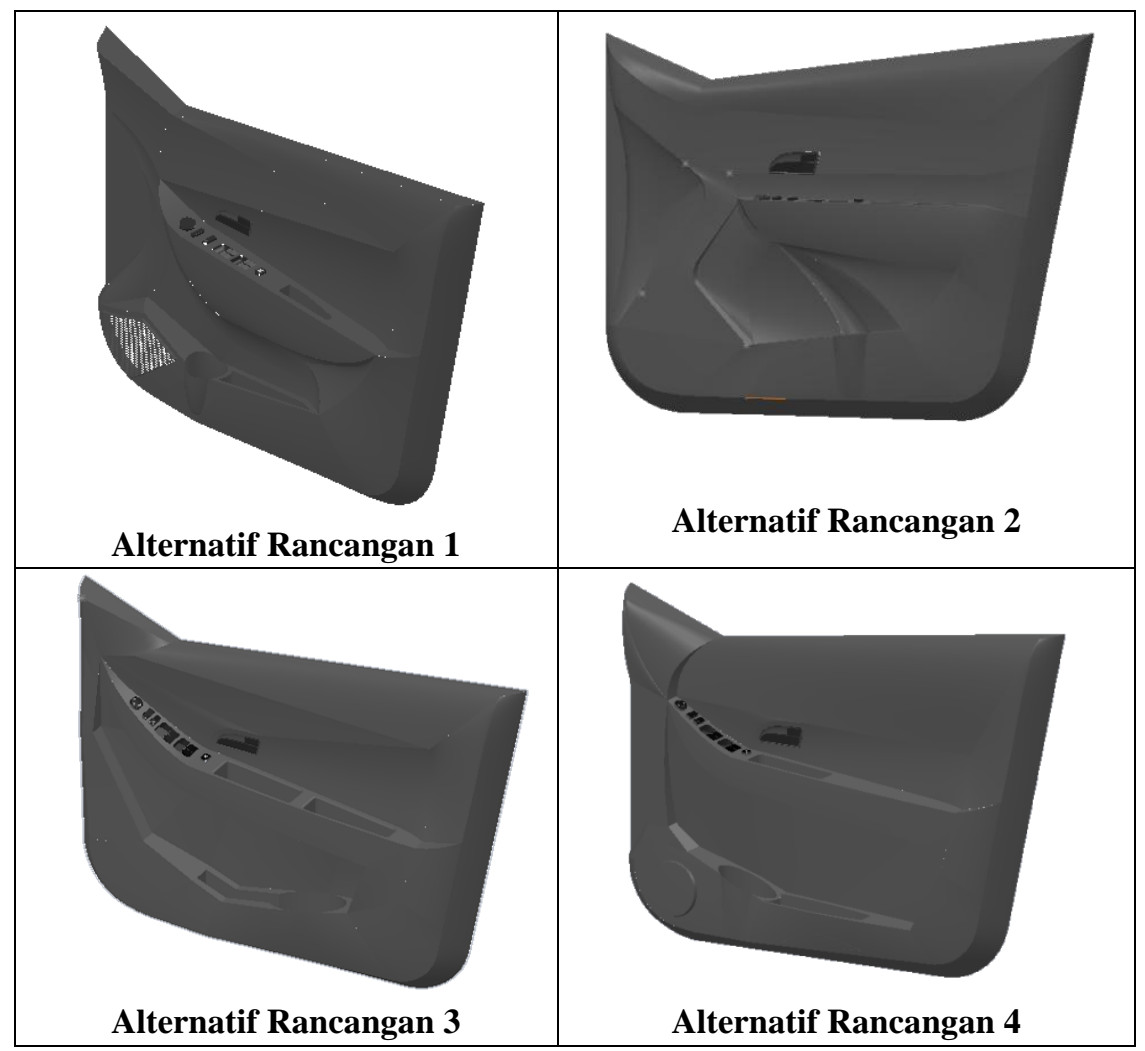

Gambar 2. Alternatif Rancangan Door trim

Tabel kombinasi konsep berikut merupakan tabel perbaikan terhadap kriteria permasalahan dengan mengeliminasi sub permasalahan dengan solusi yang lebih independen, 
misalnya pada sub permasalahan komponen pengunci pintu dan jendela dan pengaturan spion dengan solusi terkait sistem kendali yang mudah dioperasikan.

Tabel 6. Tabel Kombinasi Konsep

\begin{tabular}{|c|c|c|c|}
\hline Kriteria & $\begin{array}{l}\text { Komponen lain yang } \\
\text { menunjang keamanan } \\
\text { pengguna. }\end{array}$ & $\begin{array}{l}\text { Bentuk wadah serbaguna } \\
\text { sesuai kebutuhan pelanggan. }\end{array}$ & Kenyamanan arm rest \\
\hline $\begin{array}{l}\mathrm{K} \\
\mathrm{o} \\
\mathrm{n} \\
\mathrm{s}\end{array}$ & $\begin{array}{l}\text { Tombol pengaturan } \\
\text { jendela yang sesuai } \\
\text { dengan tempat duduk } \\
\text { penumpang. }\end{array}$ & $\begin{array}{l}\text { Wadah serba guna dirancang } \\
\text { sesuai untuk smartphone } \\
\text { ukuran } 5 \text { inchi pada posisi } \\
\text { potrait. }\end{array}$ & $\begin{array}{l}\text { Bentuknya mendatar dengan desain } \\
\text { melengkung keatas, dimana instrumen } \\
\text { handle di letakkan pada bagian bidang } \\
\text { miring yang memudahkan pandangan } \\
\text { pengemudi dan berdekatan dengan } \\
\text { kemudi. }\end{array}$ \\
\hline $\begin{array}{l}\mathrm{e} \\
\mathrm{p}\end{array}$ & & $\begin{array}{l}\text { Wadah serbaguna sesuai } \\
\text { ukuran smartphone } 7-8 \text { inchi } \\
\text { dan diletakkan bersama } \\
\text { wadah untuk botol minum. }\end{array}$ & $\begin{array}{l}\text { Bentuknya mendatar tanpa lengkungan. } \\
\text { Dilengkapi dengan instrumen handle } \\
\text { dan handle pintu. }\end{array}$ \\
\hline
\end{tabular}

Tinjauan ergonomi digunakan untuk menyelesaikan sub-sub permasalahan yang diuraikan. Misalnya untuk menyelesaikan sub masalah kemudahan pengoperasian komponen, digunakan tinjauan anthropometeri yang sesuai dengan dimensi tubuh pengguna. Dalam hal tersebut juga diberikan simbol berupa gambar dengan warna yang kontras serta memberikan kontur berupa garis-garis atau bulatan yang menonjol. Pendekatan ini dilakukan sesuai dengan prinsip display yang mampu mengkomunikasikan informasi kepada manusia dalam bentuk tanda-tanda, angka, lambang dan lain sebagainya (Sutalaksana, 1979). Simbol yang digunakan juga disesuaikan dengan prinsip yang dikembangkan dalam ISO TC 145 yakni sudah diketahui, jelas, sederhana dan logis sehingga mudah dipahami oleh pengguna (Kroemer, 2001).

Pada sub masalah kenyamanan handle pintu untuk digenggam, perancangan tersebut disesuaikan dengan dimensi anthropometri orang Indonesia yaitu lebar telapak tangan secara statis dan dinamis. Untuk kedalaman handle diukur dengan 1/3 panjang telapak tangan. Kedua ukuran ini digunakan untuk merancang panjang dan lebar handle yang nyaman digenggam. Sedangkan ketebalan handle disesuaikan dengan ketebalan jari pria dewasa pada ruas jari kedua, ditambah dengan faktor kelonggaran untuk kaos atau sarung tangan, ditambah faktor kelonggaran bebas. Henry Dreyfuss merekomendasikan minimum 1,5 inchi (38 mm) dengan 2 inchi yang lebih diutamakan $(50 \mathrm{~mm})$ (Nurmianto, 2004).

Pada sub masalah kenyamanan arm rest disesuaikan dengan dimensi tinggi siku duduk dan panjang lengan (jarak siku ke ujung jari) untuk meletakkan arm rest pada door trim. Dimensi tinggi siku diukur dari H-point pengemudi berdasarkan ketinggin $\mathrm{H} 30$ pada desain ruang kemudi. Untuk menentukan ukuran handle yang nyaman digunakan dimensi anthropometri lakilaki dengan persentil ke-95. Dengan ukuran ini komponen tersebut mampu mengakomodir kebutuhan anthropometri masyarakat yang berukuran besar. Sedangkan untuk ukuran sandaran tangan (arm rest) digunakan persentil ke-5 perempuan untuk mengakomodir kebutuhan anthropometri masyarakat yang berukuran kecil.

\subsection{Pemilihan Konsep}

Keputusan pemilihan desain pada tahap ini dilakukan berdasarkan tujuan dari perancangan door trim, yakni fokus pada dekorasi interior bersamaan dengan faktor keamanan dan ekonomi. Lebih khususnya, door trim memegang peranan penting yang berkaitan dengan fungsionalitas dan kondisi yang menyenangkan bagi pengemudi. Kondisi tersebut didefinisikan sebagai bagian dari dekorasi/tampilan door trim (Pahuja dkk.,2014). Sehingga tujuan perancangan berupa estetika dan fungsionalitas kemudian diuraikan lebih rinci dengan metode klasifikasi tujuan menggunakan objective trees. Hasil klasifikasi tujuan merupakan kriteria yang digunakan dalam matriks seleksi konsep yaitu styling, lay out, kenyamanan dan fitur. Masing-masing kriteria 
menjadi pertimbangan dalam menilai alternatif rancangan dibandingkan konsep referensi yang digunakan.

Pemilihan konsep dilakukan sesuai tahapan penilaian dalam metode Pugh yang menggunakan matriks seleksi dan konsep referensi dalam FGD. Matriks seleksi dan hasil penilaian yang dilakukan dijelaskan dalam tabel 7 , sedangkan konsep referensi yang digunakan sebagai dasar penilaian adalah alternatif desain 1 yang menjadi bagian dari alternatif rancangan pada penelitian ini.

Pemilihan konsep yang disebut sebagai seleksi konsep terdiri dari dua tahap yakni penyaringan konsep dan penilaian konsep dimana keduanya memiliki proses yang sama. Dalam penelitian ini, seleksi konsep dilakukan pada tahap pertama yakni penyaringan konsep karena melalui tahap pertama sudah didapatkan konsep yang dominan serta cukup membantu dalam membuat keputusan untuk desain yang sederhana. Selain itu, pada metode perancangan dan pengembangan produk juga dijelaskan bahwa tahap penilaian konsep dapat dilewati jika penyaringan konsep menghasilkan konsep yang dominan (Ulrich dan Eppringer, 2001).

Tabel 7. Matriks Seleksi Konsep

\begin{tabular}{cccccc}
\hline \multirow{2}{*}{ Kriteria } & \multicolumn{4}{c}{ Rancangan Door trim } \\
\cline { 2 - 6 } Estetika & I & II & III & IV \\
\cline { 2 - 6 } & Styling & 0 & - & 0 & - \\
Lay Out & 0 & - & 0 & + \\
Fungsionalitas Fenyamanan & 0 & - & 0 & + \\
Jumlah + & 0 & - & - & + \\
Jumlah - & 0 & 0 & 0 & 3 \\
Jumlah 0 & 0 & 4 & 1 & 1 \\
Nilai Akhir & 4 & 0 & 3 & 0 \\
Peringkat & 0 & -4 & -1 & 2 \\
& 2 & 3 & 4 & 1 \\
\hline
\end{tabular}

Berdasarkan tabel 7 diketahui bahwa alternatif desain terpilih merupakan desain ke-4 yang menduduki peringkat 1 dengan nilai positif sebanyak 3. Desain ke-4 dapat dilanjutkan pada tahap pengembangan desain dengan adanya perbaikan pada kontur door trim dengan memperbaiki garis rancangan yang memiliki sisi tajam menjadi bulat (round shape). Garis-garis tegas yang mengalir dengan sedikit bulatan (spherical) menjelaskan kesan dinamis yang diinginkan pelanggan. Selain diterapkan pada dashboard karakter streamline-spherical juga terdapat dalam bentuk door trim (Fanshuri, 2014). Perbaikan juga dilakukan pada desain speaker yang sebelumnya menonjol menjadi datar untuk meminimalisir biaya perancangan dan menghindari kesan penuh pada bagian bawah door trim. Hasil perbaikan dari desain terpilih dijelaskan dalam gambar 3 berikut.

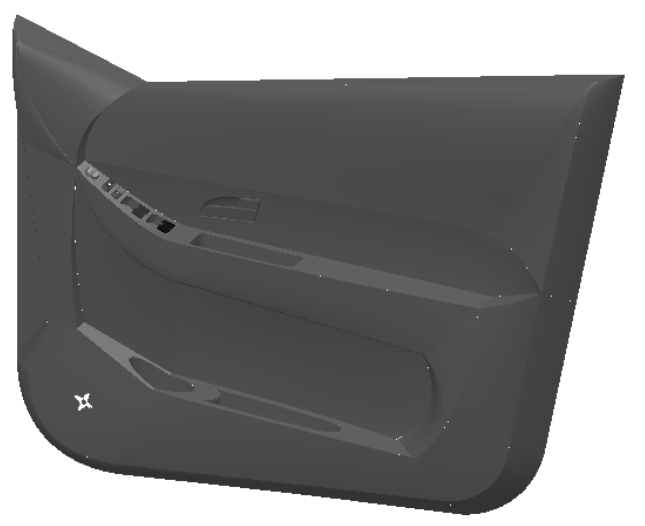

Gambar 3. Rancangan Door trim Setelah Perbaikan 


\section{Kesimpulan}

Berdasarkan penelitian yang telah dilakukan, dapat disimpulkan bahwa desain door trim dan instrumen panel yang dikembangkan untuk rancangan door trim Mobil Listrik Nasional UNS Generasi ke-2 digambarkan oleh alternatif rancangan door trim IV. Alternatif rancangan IV mendapatkan nilai tertinggi berdasarkan diskusi kelompok fokus yang dilakukan, sehingga ditetapkan sebagai konsep yang terpilih. Alternatif tersebut dirancang berdasarkan kebutuhan pengguna yang telah diidentifikasi yaitu adanya komponen yang menunjang keamanan pengguna berupa power window dan lock, adanya fitur pengaturan spion berupa retractable mirror dan electric mirror dengan knob untuk memilih spion kanan/kiri, adanya wadah penyimpan botol minum yang berada di dekat side pocket, munculnya kesan dinamis dengan bentuk kontur yang streamline-spherical dan bentuk arm rest melengkung untuk memberikan kenyamanan serta kemudahan bagi pengguna ketika mengoperasikan instrumen panel yang letaknya berdekatan.

\section{Saran}

Saran yang diberikan untuk langkah pengembangan dan penelitian selanjutnya antara lain:

1. Alternatif rancangan yang terpilih dapat dilanjutkan pada tahap pembuatan prototype door trim yang disesuaikan dengan dimensi Molina UNS.

2. Dilakukan perhitungan biaya optimal dalam pembuatan door trim terpilih

\section{Daftar Pustaka}

Fanshuri, E.F. (2014). Desain Interior Mobil Esemka Rajawali. Skripsi Sarjana-1. Jurusan Desain Produk Industri, Fakultas Teknik Sipil dan Perencanaan. Institut Teknologi Sepuluh November, Surabaya.

Febza, N. (2014). Analisis Anthropometri Desain Ruang Kemudi Mobil Listrik Nasional (MOLINA). Skripsi Sarjana-1. Jurusan Teknik Mesin dan Industri, Fakultas Teknik, Universitas Gadjah Mada, Yogyakarta.

Ishioka, M. and Yasuda, K. (2009). Product Development Concept with Product Sustainability. PICMET 2009 Proceedings, Oregon, USA.

Johnson, J.H. (2007). The Role of The Customer in the New Product Development of Radical Innovations. Dissertation.

Kroemer, K.H.E. (2001). Ergonomic : How To Design For Ease And Efficiency. Prentice-Hall Inc, USA.

Lagrosen, S. (2005). Customer Involvement In New Product Development. European Journal of Innovation Management, Vol. 8, No. 4, pp. 424-436.

Macey, S. and Wardle, G. (2008). H-POINT. The Fundamental of Car Design \& Packaging. Design Studio Press, China.

Mohamed, Z. and Yusuff, R.M. (2007). Automotive Ergonomics : Passenger Cars Interior Dimension Parameters and Comfort. Proceedings of International Conference on Ergonomics, Universiti Malaya, Malaysia.

Nurmianto, E. (2004). Ergonomi : Konsep Dasar dan Aplikasinya. Guna Widya, Surabaya.

Pahuja, D., Kapila, A., Haldar, S., and Raina, S. (2014). Five Bonding Techniques of Side Door trim Insert Skin Decoration. SAE Int. J. Mater. Manf, Vol. 7, No. 3, pp. 638-645.

Sutalaksana, I.Z., Anggawisastra, R., dan Tjakraatmadja, J.H. (1979). Teknik Tata Cara Kerja. Jurusan Teknik Industri, ITB, Bandung.

Ulrich, K.T. and Eppringer, S.D. (2001). Perancangan dan Pengembangan Produk Ed. 2. Terjemahan: Nora Azmi dan I.A. Marie. Salemba Teknika, Jakarta. 